\title{
Bacillus sp. effectivity test as a growth supressor agent from antrachnose disease caused by Colletotrichum sp. on cayenne pepper plant (Capsicum frutescens $\mathrm{L}$.)
}

\author{
Nita Widyaningsih ${ }^{1 *}$, Wisnu Adhi Susila², Annisa Khumaira ${ }^{3}$ \\ ${ }^{1}$ Bioteknologi/Sains dan Teknologi, Universitas ‘Aisyiyah Yogyakarta \\ ${ }^{2}$ Kepala Laboratorium Bakteriologi, PT Biotek Cipta Kreasi \\ ${ }^{3}$ Bioteknologi/Sains dan Teknologi, Universitas 'Aisyiyah Yogyakarta \\ nitawidyan305@gmail.com*; ${ }^{2}$ wisnu.adhi.susila@gmail.com; ${ }^{3}$ annisakhumaira@ unisayogya.ac.id \\ * corresponding author \\ Submission date: 8 April 2021, Receipt date: 19 Mei 2021, Publication date: 1 Juli 2021
}

\begin{abstract}
cayenne pepper plant (Capsicum frutescens L.) is one of the popular vegetables comodity in Indonesia. cayenne pepper plant used as main ingridients for kitchen's need, sauce industry, chili powder, instant noodle, and pharmaceutical industry. The demand for cayenne pepper plant in Indonesia is considerably high, about 4kg/capita/year. Antrachnose diseease caused by Colletotrichum sp is on of the major problem in cayenne pepper plant cultivation. Colletotrichum sp is from Nectrioidaceae family that has plenty of aservulus beneath the cuticule or on the surface. Bacillus sp has antagonist feature is consider to treat the Antrachnose disease. Bacillus sp is a marine bactreia that can produce antibiotic to fight pathogen. This test uses the antagonist test method where bacteria and fungi are grown in one medium, namely PDA. However, from this study there are two different antagonist activites between two isolate due to different chytinolytic activitiy between the two isolate.
\end{abstract}

Keywords: antagonistic activity, colletotrichum sp., bacillus sp., chitinolytic activity, heterotrophic bacteria.

\section{INTRODUCTION}

Cayenne pepper plant (Capsicum frutescens $L$.) is one of the popular vegetables comodity in Indonesia. In general, . cayenne pepper plant used as main ingridients for kitchen's need, sauce industry, chili powder, instant noodle, and pharmaceutical industry. The need for cayenne pepper in Indonesia is very high, namely: reach $4 \mathrm{~kg} / \mathrm{capita} / \mathrm{year}$ (Saraswati et al., 2002). There are several problems on cayenne pepper plant cultivation such as ; limited area, weahter, and disease from pathogen. Antrachnose diseease causes brown-black colored spots then spread into rot on stem, branch, leaf, and fruit. This diseae causes $50 \%$ market loss. Infection occurs during implantation to harvesting with the result decrease in quality and quantity of crop (Nurjasmi \& Suryani, 2020). 
Colletotrichum sp is from Nectrioidaceae family that has plenty of aservulus beneath the cuticule or on the surface, the diameter is up to $10 \mathrm{~nm}$, black colored and many setae. The setae has dark brown colored, rigid, and sharp. This fungus created a lot of sclerotium on a sick crop or medium (Firdausyi, 2005).

Massive Pesticidizing is the most common way to control the spread of the disease. Over a 60 types of pesticides used by farmers to the central production with 2-3 times a day for a week. Nevertheless, pesticides chemically damage the environtment and also reduce the quality of crop. Hence, an alternative solution is needed to control the disease without bad impact. One of the possible way to be an alternative solution is with the utilization probiotic bacteria (Nurjasmi \& Suryani, 2020). Several bacteria has antagonist feature either around the root, or endophytes with the roots. This bacteria physiologically able to produce extrcelullar enymes ( chytinase, protease, cellulase ), $\mathrm{HCN}$, phospat solvent, and flourescence activity. Bacillus sp is one of the probiotic bacteria with the capability to infect the fungi pathogen and produce mannitol and salisin (Sriyanti et al., 2015).

Probiotic bacteria inhibits the growth of pathogen with decomposing chyitin from fungus. Chitinase activity from the bacteria breaks the $\beta-1,4$ bond between $\mathrm{N}$ acetylglukosamin from chytin polymer (Wang et al., 2005), Another mechanism is to produce siderophores under conditions that are limited in iron, by binding to ferum ions needed by pathogenic fungi (Schulz et al, 2006). so that supress the hifa development of fungus. The other way for bacteria to inhibit the fungus is bind ferrum ion needed for fungus by produce limited ferrum siderophore (Triyanto et al., 2009).

Bacillus sp is a uniseluller heterotrophic bacteria and act as decomposer. Bacillus $\mathrm{sp}$ is a marine bactreia that can produce antibiotic to fight pathogen. The bacteria is able to produce several enzymes such as ; alanine and forniat, $\alpha$-amilase, isoamilase, $\beta$ amilase, glukoamilase, chitinase, dan cholesterol oxydase (Hatmanti, 2000). Therefore, a research of effectifity of bacillus sp to inhibits the growth of Colletotrichum sp is needed to reduce the use of massive pesticides.

\section{RESEARCH METHODS}

\section{Tools and materials}

Tools used for this study are; petridish glass, erlenmeyer tube, reaction tube, measuring cup, micropipete, autoclave, laminar air flow, vortex, gas stove, bunsen lamp, pan, ose, microscope, digital measurer, allumunium foil, pinset, tissue, and oven.

The materials used for this study are; cayenne pepper plant infected by Colletotrichum sp., Bacillus sp. isolate, PDA (potato dextrose agar) medium, ciprofloxacin. Lipolytic medium, celulolytic medium, amilolytic medium, pikovskaya's medium, proteolytic medium, aquades.

\section{Colletotrichum sp. isolation}

The method followed (Sriyanti et al., 2015) with modification. Infected fruits were taken from farm at P.T Biotek Cipta Kreasi. The fruit later fully washed then dried with tissue. The fruit were cut in into $0,5 \times 0,5$ size then dipped on to sodium hipoklorit 
$(\mathrm{NaClO})$ for 3 minutes. Then fruit were grew in PDA medium which contain ciprofloxacin to prevent contaminant. Medium were incubated for 3 days then subcultured until pure isolate shown.

\section{Bacillus sp. isolation}

Graded diluitoin were used for Bacillus sp. isolation. Soil were taken around the cayenne pepper plant root rizosphere at $5 \mathrm{~cm}$ deep and then added to sterilizied water. Soil were heated at $80^{\circ} \mathrm{C}$ for 10 minutes to gain bacillus sp isolate. Soil suspension were homogenated then $1 \mathrm{ml}$ soil added to reaction tube with $9 \mathrm{ml}$ sterilizied water, dilution were repeated until $10^{-4}$ (Sriyanti et al., 2015).

\section{Enzymatic Test}

- Lipolytic test

The lipolytic test followed a modified (Simamora and Sukmawati, 2020) method. Lipolytic media in $50 \mathrm{ml}$ consisted of peptone $0.01 \mathrm{~g}$, NaNO3 $0.05 \mathrm{~g}, \mathrm{CaCl} 20.05 \mathrm{~g}$, Tween-80 $0.5 \mathrm{~g}$, K2HPO4 $0.05 \mathrm{~g}$, MgSO4 $0.025 \mathrm{~g}, \mathrm{KCl} 0.025 \mathrm{~g}$, Agar $0.75 \mathrm{~g}$. The mixed material was then sterilized in an autoclave at $121{ }^{\circ} \mathrm{C}$ for 15 minutes. Bacillus megaterium bacteria were inoculated at four points of the petri dish as a repeat. Then incubated for 24 hours at room temperature. If Bacillus megaterium bacteria can grow in this medium, it can be concluded that these bacteria can dissolve lipase, this is because they are able to survive in various extreme environments, with carbohydrate content that only comes from Tween-80 (Simamora and Sukmawati, 2020).

Lipolytic, celulolytic, amilolytic, proteolytic medium was used for the enzymatic test. Pure culture of Bacillus sp. were used for the test. In lipolytic media was using tween80 solution, cellulolytic media using $0.4 \%$ CMC (Carboxyl Methyl Cellulose) material, while in amylolytic was using $1 \%$ soluble starch material. In the proteolytic test were using NA media mixed with skim milk that has been oven-dried at $80^{\circ} \mathrm{C}$ for 10 minutes (Simamora \& Sukmawati, 2020).

\section{- Cellulolytic test}

The cellulolytic assay followed a modified method (Rosalia et al, 2021). Carboxy Methyl Cellulose (CMC) media was prepared in $50 \mathrm{ml}$ with a composition of $0.1 \mathrm{~g}$ CMC; 0.025 g MgSO4.7H2O; 0.05 g K2HPO4; 0.75 g agar; 0.05 g NaNO3; 0.025 $\mathrm{KCl} ; 0.01$ peptone). The mixed material was then sterilized in an autoclave at $121^{\circ} \mathrm{C}$ for 15 minutes. Bacillus megaterium bacteria were inoculated at four points of the petri dish as a repeat. Then incubated for 24 hours at room temperature. Then lugol's iodine was added to see the clear zone. The clear zone around the bacterial colony indicates that the bacteria can dissolve cellulase (+) (Rosalia et al., 2021).

- Amylolytic test

The amylolytic assay followed the modified method (Putra et al, 2019). The amylolytic medium in $50 \mathrm{ml}$ consisted of $0.5 \mathrm{~g}$ of starch; $0.025 \mathrm{~g} \mathrm{MgSO} 4.7 \mathrm{H} 2 \mathrm{O} ; 0.05$ $\mathrm{g}$ K2HPO4; $0.75 \mathrm{~g}$ agar; $0.05 \mathrm{~g} \mathrm{NaNO} 3 ; 0.025 \mathrm{KCl} ; 0.01$ peptone. The mixed material was then sterilized in an autoclave at $121^{\circ} \mathrm{C}$ for 15 minutes. Bacillus megaterium bacteria were inoculated at four points of the petri dish as a repeat. Then incubated for 24 hours at room temperature. Then lugol's iodine was added to see the clear zone. The clear zone around the bacterial colony indicates that the bacteria can dissolve amylase (+) (Putra et al., 2019). 


\section{- Proteolytic test}

The proteolytic assay followed a modified (Manik and Simanjuntak, 2020) method. The proteolytic medium in $50 \mathrm{ml}$ consisted of $0.75 \mathrm{~g}$ agar and $0.5 \mathrm{~g}$ skim milk. Making proteolytic media by using 2 Erlenmeyer containing $25 \mathrm{ml}$ of RO water each. The first erlenmeyer contains $25 \mathrm{ml}$ of $\mathrm{RO}$ water and $0.75 \mathrm{~g}$ of agar, while the second erlenmeyer only contains $25 \mathrm{ml}$ of RO water. Then autoclaved at $121^{\circ} \mathrm{C}$ for 15 minutes. $0.5 \mathrm{~g}$ of skimmed milk in UV in LAF for 15 minutes, this is done to minimize contamination and to avoid damage to the protein in the skim milk. After the RO water in the second erlenmeyer cools, the skim milk is added and then shaken until evenly distributed. Then it was poured into the first erlenmeyer containing $25 \mathrm{ml}$ of $\mathrm{RO}$ water and $0.75 \mathrm{~g}$ of agar in a lukewarm condition. Bacillus megaterium bacteria were inoculated at four points of the petri dish as a repeat. Then incubated for 24 hours at room temperature. After 24 hours a clear zone will appear around the bacterial colony which indicates that the bacteria can dissolve proteases $(+)$ (Manik \& Simanjuntak, 2020).

- Phosphate solvent test

The phosphate solvent test followed the modified method (Walida et al, 2019). Phosphate solvent medium in $50 \mathrm{ml}$ consisted of $1,565 \mathrm{~g}$ pikov'skaya, $0.25 \mathrm{~g}$ $\mathrm{Ca} 3(\mathrm{PO} 4) 2$, and $50 \mathrm{ml} \mathrm{RO}$ water. The media was autoclaved at $121^{\circ} \mathrm{C}$ for 15 minutes. Bacillus megaterium bacteria were inoculated at four points of the petri dish as a repeat. Then incubated until a clear zone appears at room temperature. If a clear zone appears around the bacterial colony, it indicates that the bacteria can dissolve phosphate (+) (Walida et al., 2019).

\section{Antagonists Test}

The antagonist test followed the modified method (Keliat and Iftari, 2017). The antagonist test was carried out on PDA media (Potato Dextrose Agar) consisting of $0.2 \mathrm{~g}$ yeast extract, $0.2 \mathrm{~g}$ malt extract, and $1 \mathrm{~g}$ agar in $50 \mathrm{ml} \mathrm{RO}$ water (Keliat \& Iftari, 2017).

\section{RESULTS AND DISCUSSION}

\section{Bacillus sp. isolation}

Soil was taken around the cayenne pepper plant root rizosphere at $5 \mathrm{~cm}$ deep and then added to sterilizied water. Soil were heated at $80 \mathrm{oC}$ for 10 minutes to gain Bacillus sp. isolate. Bacillus sp. were taken out from rizosphere due to the bacteria around the root are able to control the pathogen by producing antibiotic substances, and nutrient space compete with pathogen (Shulz et al, 2006). The media used in this isolate was lipolytic media with the main component is Tween-80. This medium used to determine lipase activity in Bacillus sp.. The presence of lipolytic activity in Bacillus can be used as an agent to degrade the body structure of insect pests and diseases containing lipid substrates. Lipolytic test using tween 80 solution which able to detect lipase due to oleic acid ester content (Hatmanti, 2000). Bacillus sp. isolates. a clear zone is formed with the initial marking of the media from cloudy to clear. This shows that Bacillus sp are able to degrade lipid substence. Bacillus sp isolation result are shown in figure 1 . Isolate has round shape and beige colored colony. in accordance 
with the study from saputri et al (2020) that bacillus sp has small round shaped, dull white colored, and not slimy (Agustiansyah et al., 2013) [10].

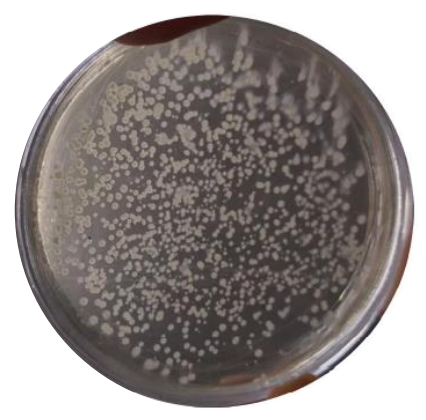

Figure 1. Bacillus sp. Isolate

\section{Bacillus sp. enzmatic test and phospate solvent result}

Enzymatic test are consist of lipolytic test, proteolytic test, amilolytic test and amilolytic test. This test used to determine enzymatic activity from bacillus sp. table 1. Enzymatic test result. Table 1 shows that bacillus sp close-related isolate has lipolytic activity characterized by the formation of clear zone around the colony in lipolytic medium.

Table 1. Enzmatic Test and Phospate Solvent Result

\begin{tabular}{ccc}
\hline No. & Perlakuan & Indeks (\%) \\
\hline 1. & Lipolytic test & + \\
2. & Amylolytic test & $62,5 \%$ \\
3. & Cellulolytic test & $48,825 \%$ \\
4. & Proteolytic test & $32,125 \%$ \\
5. & Phosphat esolvent test & $53,75 \%$ \\
\hline
\end{tabular}

Based on Table 1, it shows that the isolates close to Bacillus sp. has amylolytic activity characterized by the formation of a clear zone around the colony where the amylolytic index is $62.5 \%$. Amylolytic test is an enzymatic test that aims to determine the activity of amylase in bacteria. Amylolytic bacteria are the bacteria that can produce amylase enzymes that can break down starch into glucose. In the amylolytic test used $1 \%$ soluble starch which able to produce turbidity in the medium so that if the bacteria has amylase activity it will form a clear zone around the colony. The amylolytic test produced a clear zone with a percentage of $62.5 \%$. This clear zone appears after dropping $1 \%$ iodine, the iodine solution will be absorbed by the selective media around the clear zone so that it will produce a dark blue color (Ervina et al., 2020). Based on the research of Tampangallo (2013), the clear zone produced in the amylolytic test was $62.8 \%$. In the amylolytic test the size of the clear zone produced is smaller than the previous study. So it can be concluded that the size of the resulting diameter depends on the ability of the bacteria to hydrolyze amylase (Saputri et al., 2020). 
Cellulolytic test is an enzymatic test that aims to determine cellulase activity in bacteria. Cellulolytic bacteria are bacteria that able to produce cellulase enzymes in response to the presence of cellulose in their environment, and have the ability to hydrolyze cellulose into glucose. In the cellulolytic test, $0.4 \% \mathrm{CMC}$ was used to produce turbidity in the media so that if the bacteria had cellulase activity, a clear zone would be formed around the colony. The cellulolytic test produces a clear zone with a percentage of $48.825 \%$. Hydrolysis by the extracellular enzyme cellulase excreted by each bacterial isolate to form a clear zone. The size of the clear zone depends on the ability of each isolate to hydrolyze cellulos (Ervina et al., 2020).

Proteolytic test used to determine the activity of protease enzyme in bacteria. Proteolytic test using skim milk. Skim milk able to produce turbidity in the media so that if the bacteria have protease activity, a clear zone will be formed around the colony. The proteolytic test produced a clear zone with a percentage of $32.125 \%$, so Bacillus sp. It has very high protease activity. The clear zone formed is the result of the protein hydrolysis process, which is a white colloid suspension into derivative compounds that are more soluble and transparent (Zubaidah et al., 2019).

Phosphate solvent test aims to determine the activity of bacteria to dissolve phosphorus. Based on the phosphate solvent test, it produces a clear zone with a percentage of $53.75 \%$. The ability to dissolve phosphate is indicated by the presence of a clear zone around the bacterial colonies. This occurs due to the presence of organic acids excreted by bacteria and then binds to $\mathrm{Ca}$ ions from $\mathrm{Ca} 3(\mathrm{PO} 4) 2$ in Pikovskaya media and release $\mathrm{H} 2 \mathrm{PO} 4$ then form a clear colored area (Oksana et al., 2020).

\section{Colletotrichum sp. isolation result}

Sampling was carried out by cutting the parts of fruit that were affected by the fungus Colletotrichum sp. Then the samples were taken to the laboratory to be washed and soaked in sodium hypochlorite $(\mathrm{NaClO})$ to select the growth of fungi in the media. Image of cayenne pepper affected by Colletotrichum sp. The cause of anthracnose disease shown in Figure 2.

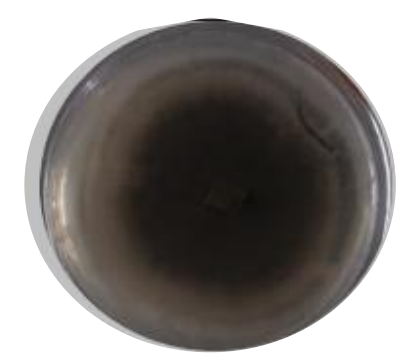

Figure 2. Colletotrichum sp. Isolate

\section{Antagonists test result}

Antagonist test aims to determine the ablity of bacillus sp to inhibits Colletotrichum sp. growth in PDA medium. From the antagoists test, There are several bacteria with antagonists properties and several bacteria without the antagonist properties as seen in table 2 . 
Table 2. Hasil Pengamatan Uji Antagonis

\begin{tabular}{ccc}
\hline $\begin{array}{c}\text { Tipe } \\
\text { Bacillus } \\
\text { sp. }\end{array}$ & Gambar & \\
\hline $\begin{array}{c}\text { Bacillus } \\
1\end{array}$ & & \\
Bacillus & & \\
A2 & & \\
\hline
\end{tabular}

The Bacillus 1 isolate do not have antagonistic activity due to the lack of activity of Bacillus sp. in hydrolyzing chitin in fungi. Meanwhile, the Bacillus A2 isolate belonging to PT Biotek Cipta Kreasi has antagonistic activity against fungi. This is because Bacillus A2 has the ability to hydrolyze chitin in fungi.

The inhibition zone around the bacterial colonies was thought to be due to the hydrolysis of chitin released by the bacteria on the cell wall of Colletotrichum sp. This causes the mycelium Colletotrichum sp. unable to grow close to the bacterial colony and appear to be damaged (Wibowo et al., 2017).

\section{CONCLUSION}

Based on intern research at PT.Biotek Cipta Kreasi, we conclude that Bacillus A2 bacteria has antagonis activity against the Colletotrichum sp. so that the bacteria able to inhibits the fungi growth. However, Bacillus sp. isolate do not have antagonists activity so that the bacteria are unable to supress Colletotrichum sp. growth that causes antrachnose on cayenne pepper plant (Capsicum frutescens L.).

\section{REFERENCES}

Agustiansyah, A., Ilyas, S., Sudarsono, S., \& Machmud, M. (2013). Karakterisasi Rizobakteri yang Berpotensi Mengendalikan Bakteri Xanthomonas oryzae Pv. oryzae dan Meningkatkan Pertumbuhan Tanaman Padi. Jurnal Hama Dan Penyakit Tumbuhan Tropika, 13(1), 42-51. https://doi.org/10.23960/j.hptt.11342-51

Ervina, E., Ekowati, C. N., Sumardi, S., \& Rosa, E. (2020). Lipolytic-screening of Bacillus genera as Biocontrol candidate In Coffee Plantation. Jurnal Ilmiah Biologi Eksperimen Dan Keanekaragaman Hayati, 7(1), 31-34. https://doi.org/10.23960/jbekh.v7i1.12 
Firdausyi, F. K. (2005). Peningkatan Peran Bakteri Bacillus subtilis Untuk Mengendalikan Penyakit Antraknosa (Colletotrichum capsici) pada Cabai Merah dengan Penambahan Tepung. Skripsi. Fakultas Pertanian. Universitas Jember.

Hatmanti, A. (2000). Bacillus spp.. Oseana, XXV(1), 31-41.

Keliat, J. M., \& Iftari, W. (2017). Uji Antagonis Fusarium sp. pada Kangkung Belerang terhadap Isolat Kitinolitik Lt4 dari Limbah Cair Tahu. Jurnal Biosains, 3(3), 140. https://doi.org/10.24114/jbio.v3i3.7899

Manik, S. S., \& Simanjuntak, S. (2020). Isolasi dan Screening Proteolitik Bakteri Termofilik Lumpur Panas Danau Linow Tomohon. Jurnal Nukleus Biosains. Vol.1(1), 12-20.

Nurjasmi, R., \& Suryani, S. (2020). Uji Antagonis Actinomycetes terhadap Patogen Colletotrichum capsici Penyebab Penyakit Antraknosa pada Buah Cabai Rawit. Jurnal Ilmiah Respati, 11(1), 1-12. https://doi.org/10.52643/jir.v11i1.843

Oksana, O., Irfan, M., Fianiray, A. R., \& Zam, S. I. (2020). Isolasi dan Identifikasi Bakteri Pelarut Fosfat pada Tanah Ultisol di Kecamatan Rumbai, Pekanbaru. $\begin{array}{llll}\text { Agrotechnology } \quad \text { Research } & \text { Journal, }\end{array}$ https://doi.org/10.20961/agrotechresj.v4i1.36063

Putra, I. B. P. ., Wirajana, I. ., \& Laksmiwati, A. A. I. A. . (2019). Selulase dan Amilase dari Daun Lontar (Borassus flabelliformis) yang telah Lapuk serta Uji Inhibisi dengan Minyak Sereh dan Cengkeh. Cakra Kimia, 7(Cmc), 140-148.

Rosalia, M., Adiartayasa, W., \& Wirawan, I. G. . (2021). Isolasi Bakteri Selulolitik dari Buah Kopi Robusta (Coffea canephora) dan Uji Kemampuan Degradasi pada Buah Kopi. Nandur, 1(1), 46-55.

Saputri, A., Soesanto, L., Umayah, A., \& Sarjito, A. (2020). Eksplorasi dan Uji Virulensi Bakteri Bacillus sp. Endofit Jagung terhadap Penyakit Busuk Pelepah Jagung. Jurnal Ilmu-Ilmu Pertanian Indonesia, 22(2), 70-78. https://doi.org/10.31186/jipi.22.2.7078

Saraswati, I. G. A. E., Pharmawati, M., \& Junitha, I. K. (2002). Karakter Morfologi Tanaman Cabai Rawit (Capsicum frustences L.) yang dipengaruhi Sodium Azida pada Fase Generatif Generasi M1. Biologi, XVI(1), 23-26.

Schulz, B.J.E., C.J.C. Boyle., T.N. Sieber. 2006. Microbial root endophytes. Springer.

Simamora, C., \& Sukmawati. (2020). Identifikasi dan Karakterisasi Aktivitas Ekstrak Kasar Enzim Lipase Isolat Bakteri Lipolitik Lptk 19 Asal Tempe Biji Karet. Median, $12,28-37$.

Sriyanti, N., Suprapta, D., \& Suada, I. (2015). Uji Keefektifan Rizobakteri dalam Menghambat Pertumbuhan jamur Colletotrichum spp. Penyebab Antraknosa pada Cabai Merah (Capsicum annuum L.). E-Jurnal Agroekoteknologi Tropika (Journal of Tropical Agroecotechnology), 4(1), 53-65. 
Triyanto, Isnansetyo, A., Prijambada, I. D., Widada, J., \& Tarmiawati, A. (2009). Isolasi, Karakterisasi dan Uji Infeksi Bakteri Proteolitik dari Lumpur Kawasan Hutan Bakau. Jurnal Perikanan (Journal of Fisheries Sciences), 11(1), 13-18. https://doi.org/10.22146/jfs.2966

Walida, H., Harahap, F. S., Hasibuan, M., \& Yanti, F. F. (2019). Isolasi dan Identifikasi Bakteri Penghasil IAA dan Pelarut Fosfat dari Rhizosfer Tanaman Kelapa Sawit. BIOLINK (Jurnal Biologi Lingkungan Industri Kesehatan), 6(1), 1. https://doi.org/10.31289/biolink.v6i1.2090

Wang, S., J. Wu., P. Rao., X. Ye. 2005. A chitinase with antifungal activity from the mung bean. Protein Expr. Purif. Vol. 40. 232-236.

Wibowo, R. H., Mubarik, N. R., Rusmana, I., \& Thenawidjaya, M. (2017). Penapisan dan Identifikasi Bakteri Kitinolitik Penghambat Pertumbuhan Ganoderma boninense in Vitro. Jurnal Fitopatologi Indonesia, 13(3), 105-111. https://doi.org/10.14692/jfi.13.3.105

Zubaidah, A., Prasetyo, D., Handajani, H., Rohmah, S. P., \& Puspita, D. A. (2019). Screening Bakteri Selulolitik dan Amilolitik pada Rumen Sapi sebagai Kandidat Probiotik pada Budidaya Ikan Secara in Vitro. Jurnal Riset Akuakultur, 14(4), 261. https://doi.org/10.15578/jra.14.4.2019.261-271 